\title{
阪神・淡路大震災の記憶等を伝える公園及び公園施設等の現状と課題
}

\section{Present Situation and Issues of Parks and Park Facilities which Transmit Memories of the Great Hanshin -Awaji Earthquake Disaster}

\author{
橘 俊光* 平田富士男**
}

\section{Toshimitsu TACHIBANA Fujio HIRATA}

\begin{abstract}
Many local governments in the area struck by the Great East Japan Earthquake incorporated construction plan of memorial parks which transmit memories and lessons of earthquake disaster into the restoration plans from the earthquake disaster. But there is no model design plan, or management plan to be referred for the planners who will make these plans. On the other hand, in Hyogo Prefecture there are many parks and park facilities which were constructed in the restoration projects after the Great Hanshin-Awaji Earthquake Disaster to transmit memories of the earthquake disaster and have been managed for these nearly fifteen years at the longest. So, this research is aimed to get many suggestions for design and management plans of earthquake disaster memorial parks which will be constructed in East Japan, by analyzing present situation and the past history of earthquake disaster memorial parks in Hyogo Prefecture. As the results, we made clear that 1) Facilities in memorial parks which transmit memories of earthquake are classified into four groups of facilities for transmitting the memories or lessons and one group of facilities for giving benefits to users, 2) Facilities for transmitting the memories or lessons are thought to be effective by the managers, 3) Remains of earthquake should be conserved against disapproval of citizens in early time, because the needs for conservation increase later according to citizens' consciousness changes, and so on.
\end{abstract}

Keywords: the Great East Japan Earthquake Disaster, earthquake disaster memorial park, the Great Hanshin-Awaji Earthquake Disaster

キーワード： 東日本大震災, 震災記念公園, 阪神・淡路大震災

\section{1. はじめに}

東日本大震災の震災復興計画では，各地で震災の記憶を後世に 伝えようとする震災復興祈念・記念公園等（以下「震災記念公園」 という）が盛り込まれており，国土交通省の調べによると, 2012 年 3 月現在で東北から関東地方にかけての 7 県で 47 もの震災記 念公園が復興計画に位置付けられている ${ }^{1)}$ 。今後このような公園 が次々と具体的に事業化され，施設内容の計画設計や管理運営計 画の検討が行われてくることとなるが，震災の記憶を伝える公園 としての機能を永遠に発揮し続けていくためには，当初のハード デザインだけではなく，その後の維持管理運営も含めた長期的な 観点から公園のあり方を考えておく必要がある。しかし，このよ うな震災記念公園のあり方については，一定のまとまった知見が 蓄積されているわけではなく，今後各所で整備される震災記念公 園の整備・管理運営のあり方を検討していくにあたっては，その 検討段階で多くの課題に直面することが予想される。

一方，阪神・淡路大震災（以下「阪神大震災」という）の復興 事業においては多くの都市公園が整備され，そのなかには相当数 の震災記念公園や震災の記憶を後世に伝えようとする公園的施設 (以下「公園施設等」という）が整備されており，それらは設置 後 10 数年を経て, ほとんどが設置当時のまま管理運営されてき ていると考えられる。阪神大震災の記憶を伝えようとするこれら の震災後 17 年あまりを経た現状を分析することは, 今後, 東北地 方等において整備されようとする震災記念公園や公園施設等の整 備や管理運営のあり方に多くの示唆を与えるものとなることが考 えられる。

しかし，阪神大震災復興事業によって整備された公園の内容に ついは, 橘ら ${ }^{2)}$ が兵庫県における公園緑地の内容を整理してま とめているが，今後の防災の観点からの分析が主であり，震災記 念公園や公園施設等のあり方については分析がなされていない。
また，田中 ${ }^{3)}$ は，神戸市の震災復興事業における公園緑地の整備 やそれを含めたまちづくりにおける市民参画の状況を分析してい るが、それによる震災の記憶を伝える機能の発揮ということにつ いてまでは言及していない。

そこで本研究は, 発災から 17 年強を経て, 阪神大震災の復興 事業において整備された震災記念公園や公園施設等の現状を網羅 的に把握，分析し，また，これまでの管理運営の経験も踏まえた 管理担当者等の知見をもとに，今後東北地方等において整備され ようとするこれらのあり方に対する示唆を得ることを目的とする。

\section{2. 研究の方法}

本研究は，東北地方等の震災記念公園等の整備および管理運営 にあたって有用となる情報を得ることを目的としていることから， まず，東北地方等における震災記念公園等の検討にあたって必要 としている情報項目を東北地方で整備計画指導にあたっている国 土交通省担当官から聴取・把握し，そこで必要とされる情報を中 心に阪神大震災被災地域から網羅的に収集・分析寸る方法を採つ た。

具体的には以下の手順により行った。

(1)東北地方整備局の公園担当官から，今後の震災記念公園等の計 画検討にあたって必要となる情報について聞き，ヒアリングシー トを作成した。

(2)阪神大震災被災地域内（13 市）の都市公園担当者に，震災の記 憶を伝える公園および公園施設等の抽出を依頼した。

抽出にあたっては，今後の東北地方等の震災記念公園等の整備 に参考となる知見を得ることを目的としていることから, 調査対 象としては公園内に設けられた単独の小規模な記念碑などは除く こととし，以下の条件とした。

・都市公園（あるいは都市公園に類する屋外施設を含む）そのも

\footnotetext{
*兵庫県県土整備部/兵庫県広域防災センター **兵庫県立大学大学院緑環境景観マネジメント研究科/兵庫県立淡路景観園芸学校
} 
表-1 阪神・淡路大震災の記憶を伝える都市公園及び都市公園施設の現状等と施設の類型

\begin{tabular}{|c|c|c|c|c|c|c|c|c|c|}
\hline \multicolumn{2}{|c|}{ 項 目 } & \multicolumn{2}{|c|}{ 水笠通公園 } & \multicolumn{2}{|c|}{ 千歳公園 } & \multicolumn{2}{|c|}{ みなとのもり公園 (神戸震災復興公園) } & 芦屋公園 & 西宮震災記念碑公園 \\
\hline I. 施 & a.位置 & \multirow{2}{*}{\multicolumn{2}{|c|}{$\begin{array}{c}\text { 神戸市長田区水箁通2丁目 } \\
\text { 近隣公園 }\end{array}$}} & 神戸市須磨区干 & 歳町2丁目 & \multicolumn{2}{|c|}{$\begin{array}{l}\text { 神戸市中央区小野浜町 } \\
\end{array}$} & 芦屋市浜芦屋町22 & 西宮市奥畑45-6 \\
\hline 設が存 & b.種別 & & & \multicolumn{2}{|c|}{ 近隣公園 } & \multicolumn{2}{|c|}{ 総合公園 } & 近隣公園 & 街区公園 \\
\hline 在する & \begin{tabular}{|l|l} 
c.面積 \\
\end{tabular} & \multirow{2}{*}{\multicolumn{2}{|c|}{$\begin{array}{c}1.0 \mathrm{ha} \\
2007 \text { 年3月 }\end{array}$}} & \multirow{2}{*}{\multicolumn{2}{|c|}{$1.0 \mathrm{ha}$}} & \multicolumn{2}{|c|}{$5.6 \mathrm{ha}$} & $2.9 \mathrm{ha}$ & $0.5 \mathrm{ha}$ \\
\hline 公園等 & \begin{tabular}{|l|} 
d.開設年度 \\
\end{tabular} & & & & & \multicolumn{2}{|c|}{ 2010年1月17日 } & 1908年 & 1997年 \\
\hline の属性 & e.設置主体 & \multicolumn{2}{|c|}{ 神戸市 } & \multicolumn{2}{|c|}{ 神戸市 } & & & 芦屋市 & 西宮市 \\
\hline に関す & \begin{tabular}{|l|l} 
f.管理体制 \\
\end{tabular} & \multicolumn{2}{|c|}{ 市直営(地元公園管理会あり) } & \multicolumn{2}{|c|}{ 市直営(地元公園管理会あり) } & \multicolumn{2}{|c|}{ 市直営 } & 市直営 & 市直営 \\
\hline る事項 & g. 入園料. 入場料 & \multicolumn{2}{|c|}{ な } & \multicolumn{2}{|c|}{ なし } & \multicolumn{2}{|c|}{ なし } & $\begin{array}{c}\text { なし } \\
\end{array}$ & $\begin{array}{c}\text { なし } \\
\end{array}$ \\
\hline \multirow{4}{*}{ 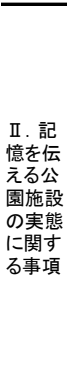 } & a. 施設内容 & $\begin{array}{l}\text { 世せらぎ水路,園 } \\
\text { 内延長約100m }\end{array}$ & $\begin{array}{l}\text { 震災復興の } \\
\text { 碑,水笠通2 } \\
\text { 丁目の碑 }\end{array}$ & $\begin{array}{l}(\text { No.1) メタセコイア } \\
\text { (保存樹)の根元の } \\
\text { 部分.記念碑「千歳 } \\
\text { 復興の礎」,80cm角 } \\
\times \text { × } 600 \mathrm{~cm}\end{array}$ & $\begin{array}{l}(\text { №.2) 焼け止 } \\
\text { まりになつた } \\
\text { 樹木の移植 } \\
\text { W150×H120 } \\
\times \text { D50 }\end{array}$ & $\begin{array}{l}\mid \text { 広場(「語り継ぎ広 } \\
\text { 場」),3,500m² }\end{array}$ & \begin{tabular}{|l} 
モニュメント(時計), \\
高さ約 $4 \mathrm{~m}$
\end{tabular} & $\begin{array}{l}\text { 石づくりの記念碑(市 } \\
\text { 内の震災犠牲者名簿 } \\
\text { を收める,碑文石),,設 } \\
\text { 置部約 } 22 \mathrm{~m}^{2}\end{array}$ & $\begin{array}{l}\text { 石つ゚くりの記念碑 } W 920 \mathrm{~cm} \times \mathrm{H} 300 \mathrm{~cm} \times \\
\text { D60cmの稲田石にに市内の震災犠牲者追 } \\
\text { 悼の碑,碑文石,震災記録碑,震災記録写 } \\
\text { 真碑をは込み,献花台高約 } 50 \mathrm{~cm}\end{array}$ \\
\hline & b. 設置の目的 & $\begin{array}{l}\text { 震災後の水の確 } \\
\text { 保の苦労を伝え, } \\
\text { 有事は仮設トイ } \\
\text { し給水として活 } \\
\text { 用。水の備えの } \\
\text { 啓発 } \\
\end{array}$ & $\begin{array}{l}\text { 震災復興の } \\
\text { 記念·震災の } \\
\text { 記憶を後世 } \\
\text { に伝える }\end{array}$ & $\begin{array}{l}\text { 復興の記念碑とし } \\
\text { て震災10周年に設 } \\
\text { 置 }\end{array}$ & $\begin{array}{l}\text { 震永の記憶 } \\
\text { を伝える }\end{array}$ & \begin{tabular}{|l|} 
震兹復興の経験と教訓 \\
後世に伝えるる場として, \\
被災樹木や被災建物の \\
一部をオブジェ的に設 \\
置。震災復興のシンジル
\end{tabular} & \begin{tabular}{|l|}
$J R$ 貨物神戸港駅時 \\
代にここで使われ \\
ていた時計を震災 \\
の時刻を指すこと \\
で記憶を留める
\end{tabular} & $\begin{array}{l}\text { 震災の記憶と教訓を } \\
\text { 留める }\end{array}$ & 犠牲者の追悼,震災の記録を留める \\
\hline & c.設置時期 & 2007年3月 & 2009年3月 & 2005 年 & $1995 \sim 1996$ & \multicolumn{2}{|c|}{ 2010年1月17日 } & 1996年 & 1998年1月17日 \\
\hline & $\begin{array}{l}\text { d.利用状況 (主な利 } \\
\text { 用者,震災記念式典 } \\
\text { など) }\end{array}$ & $\begin{array}{l}\text { 平時は,子どもた } \\
\text { ちの水遊び場と } \\
\text { して常に利用 }\end{array}$ & & \multicolumn{2}{|l|}{ 一般公園利用者 } & \multicolumn{2}{|c|}{$\begin{array}{l}\text { 一般の公園利用者,なお,公園全体としては震 } \\
\text { 災から15年目の1月17日に開園式典を開售。 } \\
\text { その後も様々なイベント等で活用されている }\end{array}$} & $\begin{array}{l}\text { 毎年1月17日に記帳 } \\
\text { 所を設置,献花を受 } \\
\text { 付。変わらず多の人 } \\
\text { が訪れる }\end{array}$ & $\begin{array}{l}\text { 毎年1月17日に記帳所を設置,献花を受 } \\
\text { 付。変わらすず多くの人が訪るる。H24年は } \\
\text { 2,400人 }\end{array}$ \\
\hline \multicolumn{2}{|c|}{$\begin{array}{l}\text { 吕.施設設置経緯等に関す } \\
\text { る事項 }\end{array}$} & $\begin{array}{l}\text { 2004年,公園の } \\
\text { ワークラショプの } \\
\text { 中で地元から要 } \\
\text { 望があり整備し } \\
\text { た }\end{array}$ & & & & \multicolumn{2}{|c|}{ 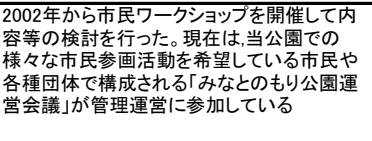 } & 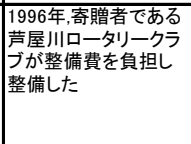 & $\begin{array}{l}\text { 市の震災復興計画で「震災復興記念公 } \\
\text { 園建設」が明記,庁内検討委員会でで犠 } \\
\text { 牲者の氏名の表示方法(刻銘か、名簿納 } \\
\text { 室か)の検討を経て,遺族の意見も聞きな } \\
\text { がら決定。犠牲者の刻銘にこついては当初 } \\
\text { 約5\%の遺族が望まず }\end{array}$ \\
\hline \multicolumn{2}{|c|}{ 施設の類型 } & 防災教育 & $\begin{array}{l}\text { 新たな記念 } \\
\text { 碑 }\end{array}$ & 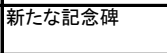 & \begin{tabular}{|l} 
震災遺構保 \\
存
\end{tabular} & 震災遺構保存 & 震災遺構保存 & $\begin{array}{l}\text { 新たな記念碑,儀牲者 } \\
\text { 追悼·慰霊 }\end{array}$ & 新たな記念碑,儀牲者追悼·慰霊 \\
\hline
\end{tabular}

表-2 阪神・淡路大震災の記憶を伝える都市公園以外の公園的施設の現状等と施設の類型

\begin{tabular}{|c|c|c|c|c|c|c|c|c|}
\hline \multicolumn{2}{|r|}{ 目 } & 神戸港震災メモリアルパーク & \multicolumn{6}{|c|}{ 北淡震災記念公園 } \\
\hline \multirow{6}{*}{$\begin{array}{l}\text { I. 施 } \\
\text { 設が存 } \\
\text { 在する } \\
\text { 公園的 } \\
\text { 施設の } \\
\text { 禹性に } \\
\text { 事朩項る }\end{array}$} & a.位置 & 神戸市中央区波止場町 & & & 淡路市小倉1 & & & \\
\hline & b.面積等 & 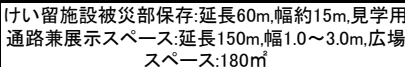 & \multicolumn{6}{|c|}{ 3.4ha } \\
\hline & c.開設年度 & 1997年7月15日 & \multicolumn{6}{|c|}{ 1998年 } \\
\hline & d. 設置主体 & $\begin{array}{c}\text { 保存部分: 国,神戸市,その他部分: 神戸港振興協 } \\
\text { 会(後にに神戸港振興協会より神戸市へ䓫付) }\end{array}$ & \multicolumn{6}{|c|}{ 当時の北淡町 (現淡路市) } \\
\hline & \begin{tabular}{|l|} 
e.管理体制 \\
\end{tabular} & $\begin{array}{c}\text { 指定管理者:神戸港振興協会 } \\
\end{array}$ & \multicolumn{6}{|c|}{$\begin{array}{c}\text { 指定管理者:侏|ほくだん } \\
\end{array}$} \\
\hline & f. 入園料 $\cdot$ 入場料 & $\begin{array}{c}\text { なL } \\
\end{array}$ & \multicolumn{6}{|c|}{ 700円/大人(ただし,神戸の壁,べっちやないロックは無料区域) } \\
\hline \multirow{4}{*}{$\begin{array}{l}\text { II. 記 } \\
\text { 憶を伝 } \\
\text { える公 } \\
\text { 施設 } \\
\text { の容態 } \\
\text { に関す } \\
\text { る事項 }\end{array}$} & a. 施設内容 & 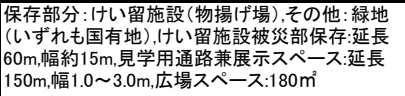 & $\begin{array}{l}\text { 野島断層保存館:震災の遺 } \\
\text { 教保在示,教育施設,約 } \\
\text { 1,500m² }\end{array}$ & $\begin{array}{l}\text { 震災体験館:震災の } \\
\text { m } \\
\mathrm{m}^{2}\end{array}$ & \begin{tabular}{|l|} 
メモリアルハウス: \\
震災の被害の展 \\
示,教育施設,約 \\
$200 \mathrm{~m}^{2}$
\end{tabular} & \begin{tabular}{|l|} 
神戸の壁:震災遺構 \\
展示施設
\end{tabular} & \begin{tabular}{|l|} 
活断層ラボ: \\
震災連教 \\
育施設,約150 \\
$\mathrm{m}^{2}$
\end{tabular} & $\begin{array}{l}\text { ベっちゃないロック } \\
\text { (震災モニュメント,鎮 } \\
\text { 魂の碑,犠牲者慰霊 } \\
\text { 碑),約 } 1,500 \mathrm{~m}^{2}\end{array}$ \\
\hline & b. 設置の目的 & 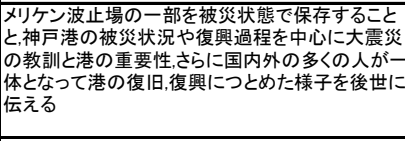 & 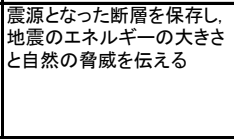 & 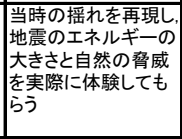 & $\begin{array}{l}\text { 断層上の民家を保 } \\
\text { 存し,震災の記憶を } \\
\text { 伝ええ,風化させせい } \\
\text { ようにする }\end{array}$ & 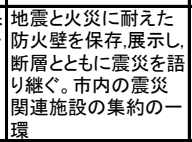 & \begin{tabular}{|l|} 
地震の仕組 \\
みや世界の \\
地震の状況 \\
など幅広く地 \\
震にについて学 \\
ぶ
\end{tabular} & \begin{tabular}{|l} 
震災の記滰を留め, \\
犠牲者を㮣雷する \\
\end{tabular} \\
\hline & c.設置時期 & 1997年7月15日 & 1998年 & 2004年 & 1999年4月 & 2009年1月 & 2008年3月 & 1999年4月 \\
\hline & d. 利用状況 & 社会見学,国内外の観光客等 & \multicolumn{5}{|c|}{ 2011年度は年間約21万人(1998年:282万人, 1999 年:140万人) } & $\begin{array}{l}\text { 毎年1月慰霊祭開 } \\
\text { 催。定期的な地元の } \\
\text { 祭り }\end{array}$ \\
\hline \multicolumn{2}{|c|}{$\begin{array}{l}\text { 吕.施設設置経緯等に関す } \\
\text { る事項 }\end{array}$} & 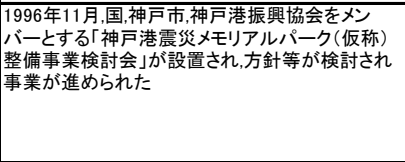 & 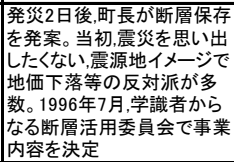 & $\begin{array}{l}\text { 保存館と同時に断層 } \\
\text { 活用委員会の意見 } \\
\text { 走聴きながら計画し } \\
\text { た } \\
\end{array}$ & \begin{tabular}{|l|}
$\mid$ 保存館と同時に計 \\
画した
\end{tabular} & & & \\
\hline \multicolumn{2}{|c|}{ 施設の類型 } & 震災遺構保存,防災教育 & 震災遺構保存,防災教育 & 防災教育 & \begin{tabular}{|l} 
震災遺構保存,防 \\
災教育
\end{tabular} & 震災遺構保存 & 防災教育 & $\begin{array}{l}\text { 新たなな記念碑,儀牲 } \\
\text { 者追悼·㶪霊 }\end{array}$ \\
\hline
\end{tabular}

のが震災の記憶を伝えることを主目的として設置されたもの ・震災の記憶を伝えることを主目的とはしていなくとも公園内に 複数の震災の記憶を伝える公園施設が設けられているもの

・上記以外の単独の公園施設であっても施設の規模が大きく，震 災の記憶を伝える施設としてその市の代表的なものとなっている もの

(3)それらの公園および公園施設等について，それぞれの公園管理 者を訪問してヒアリングシートに基づきヒアリングを実施した。 そして，阪神大震災の記憶を伝える都市公園及び都市公園施設と して，神戸市では水笠通公園，千歳公園，みなとのもり公園（神 戸震災復興公園）(以下，「みなとのもり公園」と表示）を，芦屋 市では芦屋公園, 西宮市では西宮震災記念碑公園を (表 - 1), 都 市公園に類する公園的施設としては神戸港震災メモリアルパーク (神戸市・港湾施設）と北淡震災記念公園（淡路市）を抽出した (表 -2$)$ 。

ヒアリング項目は，以下のとおりである。
・公園や公園施設の現況に関する事項として，公園等の位置，規 模, 開設時期, 施設の内容, 施設の設置目的, 設置の経緯（設置 に対する反対意見の有無など)，管理主体・体制，利用状況など ・公園の管理運営を踏まえた課題に関する事項としては，利用状 況の変化，管理運営を行ってみてわかった整備内容への反省，管 理運営上課題と感じていること, 東北地方等で今後整備される同 様の施設に対するアドバイスなど

また，現地で施設内容の調査，利用状況資料収集を行った。

なお，調查の時期は 2012 年 8 月～9 月上旬である。

\section{3. 結果}

(1)施設の現状、施設の類型への把握

ヒアリング結果の概要を表 - 1 及び - 2 に示す。震災の記憶を 伝えようとしている公園施設等の類型を整理すると以下のように なった（表 - 1 及び - 2 の最下段参照）。

(1)震災遺構保存施設（震災の記憶を伝えるために遺構を保存す 
表-3 阪神・淡路大震災の記憶を伝える公園等施設の現在の運営実態に関する意見等

\begin{tabular}{|c|c|c|c|c|}
\hline & 目 & $\begin{array}{c}\text { みなとのもり公園 (神戸震災復 } \\
\text { 興公園) }\end{array}$ & 神戸港震災メモリアルパーク & 北淡震災記念公園 \\
\hline \multirow[b]{3}{*}{$\begin{array}{l}\text { I. 記憶 } \\
\text { を伝える } \\
\text { 公園等 } \\
\text { 施設の } \\
\text { 誢在の } \\
\text { 運営実 } \\
\text { 態に関 } \\
\text { する事項 }\end{array}$} & 1.管理運営主体 & 神戸市 & 神戸市(指定管理者: 神戸港振興協会) & (株)ほくだん \\
\hline & $\begin{array}{l}\text { 2.管理運営業務 } \\
\text { 内容 }\end{array}$ & 清掃,植栽管理 & $\begin{array}{l}\text { 施設の利用及びその制限に関する業務,施設の利用 } \\
\text { 料の徵収等の業務,設備等保守点検業務,警備,清掃 } \\
\text { 業務等 }\end{array}$ & 物産館,セミナーハウス等を含めた公園の総合的な管理運営 \\
\hline & \begin{tabular}{|l} 
3.施設の運営実 \\
態に関する状 \\
況、課題、評価 \\
等
\end{tabular} & $\begin{array}{l}\text { (1)樹木の一部の枯損がでてい } \\
\text { ること。 } \\
\text { (2)被災樹木として,長田区で焼 } \\
\text { け止まりとなったクスノキ等を } \\
\text { 移植してきたが,今後も枯損し } \\
\text { ないように保てるかどうか不安 } \\
\text { がある。 } \\
\text { (3)市内学校の遠足や社会見 } \\
\text { 学の対象となっていたり,他都 } \\
\text { 市等による視察が多いことな } \\
\text { どから一定の役割は果たせて } \\
\text { いるのではないかと考える。 }\end{array}$ & 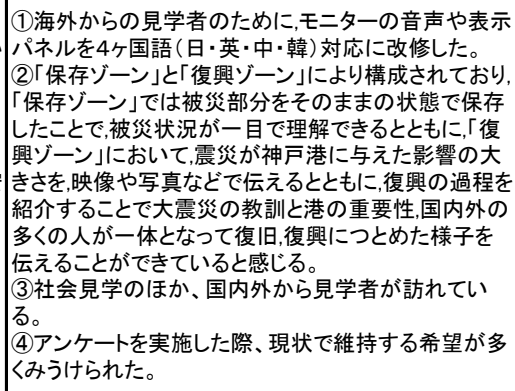 & 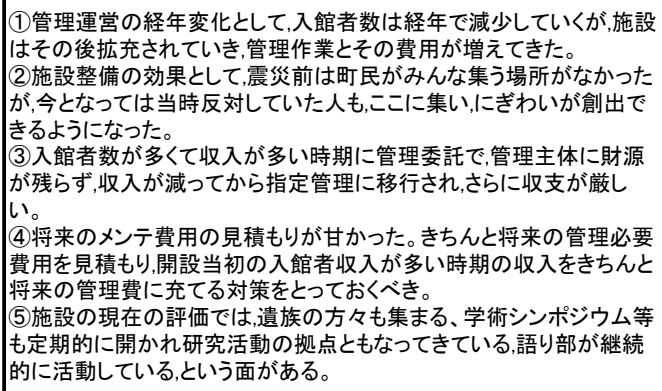 \\
\hline \multirow[b]{2}{*}{$\begin{array}{l}\text { I. I. . } \\
\text { 外の施 } \\
\text { 設の実 } \\
\text { 態に関 } \\
\text { する事項 }\end{array}$} & 1.施設の内容 & $\begin{array}{l}\text { 芝生広場,苗圑,ジョギングコー } \\
\text { ス,備蓄倉庫,災害用仮設トイ } \\
\text { レ,ニュースホーーツ広場,非常用 } \\
\text { 自家発電装置 }\end{array}$ & 「神戸海洋博物館」 & レストラン,物産館,セミナーハウス,風力発電施設 \\
\hline & $\begin{array}{l}\text { 2. I.の施設とあ } \\
\text { いまってその存 } \\
\text { 在が効果的だと } \\
\text { 思えるもの及び } \\
\text { その理由 }\end{array}$ & $\begin{array}{l}\text { (施設) 備蓄倉庫や災害用仮 } \\
\text { 設トイレなど各種防災関係施 } \\
\text { 設,(理由)イベントや防災訓練 } \\
\text { など様々な機会を通じて,震災 } \\
\text { の経験と教訓を継承すること } \\
\text { が可能となる。 }\end{array}$ & $\begin{array}{l}\text { I.の施設に隣接し,港に関する震災の記録,その他関 } \\
\text { 係資料を収集,保管するとともに,館内に展示スペース } \\
\text { を設けている。 }\end{array}$ & 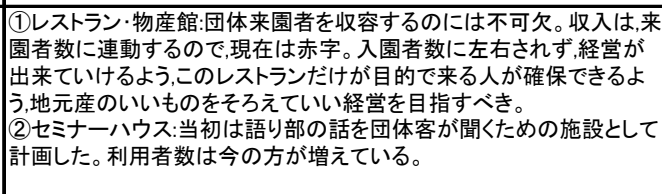 \\
\hline
\end{tabular}

表-4 阪神・淡路大震災の記憶を伝える公園等施設の実態を踏まえた東北地方等へのアドバイス

\begin{tabular}{|c|c|c|}
\hline 施設名 & 当当課等 & アドバイスの内容 \\
\hline $\begin{array}{l}\text { みなとのもり } \\
\text { 公園 (神戸 } \\
\text { 震災復興公 } \\
\text { 園)(神戸 } \\
\text { 市) }\end{array}$ & $\begin{array}{l}\text { 神戸市建 } \\
\text { 設局公園 } \\
\text { 砂防部緑 } \\
\text { 地課 }\end{array}$ & 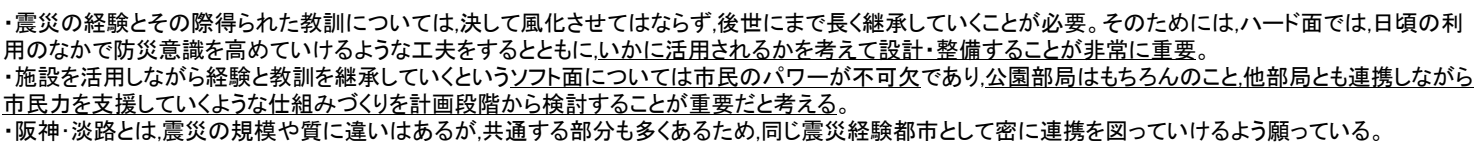 \\
\hline $\begin{array}{l}\text { 西宮震災記 } \\
\text { 念碑公園 } \\
\text { （西宮市） }\end{array}$ & 宮市公 & 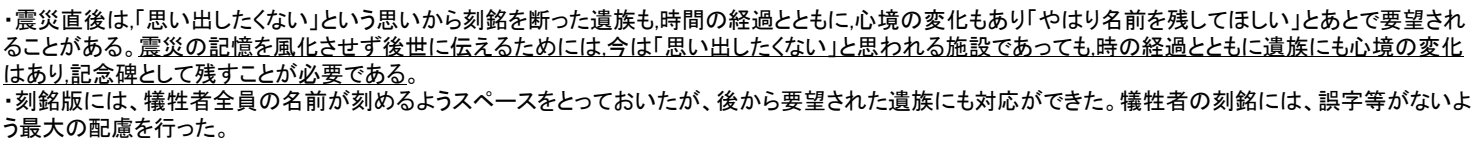 \\
\hline $\begin{array}{l}\text { 北淡震災記 } \\
\text { 念公園 (淡 } \\
\text { 路市) }\end{array}$ & $\begin{array}{l}\text { (株)ほく } \\
\text { だん(指定 } \\
\text { 管理者) }\end{array}$ & 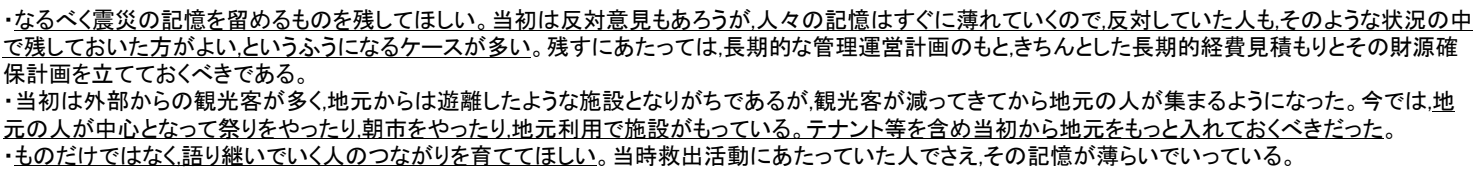 \\
\hline
\end{tabular}

る）:千歳公園 (焼け残った樹木の移植)，みなとのもり公園 (「語 り継ぎ広場」，モニュメントに残された時計），神戸港震災メモリ アルパーク (被災したけい留施設), 北淡震災記念公園 (野島断層 保存館，メモリアルハウス，神戸の壁)

(2)新設の記念碑 (遺構保存ではなく新たに記念碑をつくる) :水笠 通公園，千歳公園，芦屋公園，西宮震災記念碑公園，北淡震災記 念公園

(3)犠牲者追悼·慰霊碑（震災の犠牲者を碑等で追悼・慰霊する）： 芦屋公園, 西宮震倓記念碑公園, 北淡震災記念公園

(4)防災教育施設 (防災意識を高めたり防災教育に資する) : 水笠通 公園 (せせらぎ水路二被災時の水の大切さを伝える施設), 北淡震 災記念公園（震災体験館，メモリアルハウス，活断層ラボ）

(5)利用者の利便のための便益施設 : 北淡震災記念公園（レストラ ン, 物産館)

これらの施設が現在，震災の記憶を伝えるという所期の目的を 達成しているかどうかについては，各担当者とも高く評価してお り，今後の震災記念公園の計画にあたっては，これら類型施設を ベースとして検討寸ることが効果的であると思われる。

(2)施設計画時の市民意見とそれへの対応
これらの施設のうち，その整備について市民間でも意見が分か れるものとして，震災当時を伝える，記憶を思い起こす遺構を保 存するものや犠牲者各個人の名前を記載し追悼・慰霊する碑があ る。現地の担当者に計画当初からこれまでのことを振り返っても らうと, 建設に当たって当初, 震災を思い出したくない, 震源地 のイメージが地価に影響寸る (北淡震災記念公園), 犠牲者氏名の 刻銘はつらい（西宮震災記念碑公園では，当初，犠牲者遺族の約 5\%が犠牲者の刻銘を望まず）などの反対意見があったものの，現 在では反対意見はなく，逆に良かったとの意見，さらには当時刻 銘を固辞していたが，その後やはり刻銘の希望申し出のあるケー スなども多く, 各市担当者もこのような施設の整備は推進すべき との強い意見であった。北淡震災記念公園では，現在では当時反 対していた人たちも含め市民の集いの場, 遺族も集まる場となり, にぎわい創出の場となっており，また，語り部の継続的な活動の 場ともなっている。西宮震災記念碑公園では，犠牲者氏名の表示 方法でも石碑に刻銘するやり方と名簿にして石室に納める方法と の議論があったが，議論の末，石碑に刻銘する方法に決まり，具 体的な整備においては直接手で触れることができる，車いすでア クセスできる，などの意見を踏まえた対応がとられた。みなとの 
もり公園, 水笠通公園では, 当初からワークショップ等により施 設計画に市民意見を反映させる方法が採られてきた。このように， 担当者からは被災者遺族等の心情，意見に沿った整備の必要性と 同時にそれら被災者遺族等の心情は，時間の経過とともに変化す ることもあるので，それを受け止められるような対応をとってお く必要性(たとえば, 犠牲者刻銘については追加刻銘ができるよう なスペースをとっておくなど)が指摘された。

ここで重要なのは，被苂者遺族等の心情は時間とともに変化す ることがあるということで，注目すべきは，北淡震災記念公園の 担当者が語るように(表 - 4) 周囲を含めた人の記憶が急速に薄れ ていくという危機感であり，それを感じた遺族のなかには，当初 反対していた遺構の保存や犠牲者の刻銘に対して，その必要性を 感じるようになる人もいるのではないかと思われる。

\section{(3) 管理運営の実態等}

管理運営に関する意見等についてのヒアリング結果の概要を表 - 3 に示す。管理運営業務の内容は以下のように分類できる。

(1)震災遺構保存施設等を適切に維持寸る通常の維持業務 : 水笠通 公園，千歳公園ほ力全公園

(2)震災遺構保存施設や防災教育施設を活用して震災の記憶を伝え ようとする運営業務 : 芦屋公園, 西宮震琰記念碑公園, 神戸港震 災メモリアルパーク，北淡震災記念公園

(3)震災遺構保存施設や防㷋教育施設に限らず公園内の施設全体を 活用して震災の記憶を伝えようとする運営業務 : みなとのもり公 園

(4)関連する利用者のための便益施設等の運営，経営 : 北淡震災記 念公園

このうち，(1)では，記念碑·慰霊碑等に対して，当初から，ある いは最近では震災を経験していない子どもが増えてくる中でいた ずらの心配が懸念されていたが，実態としてはその心配はほとん どないようである。

(2)では, 毎年の慰霊行事の開催のほか, ボランティアによる語 り部など多様なプログラムが展開されている。北淡震災記念公園 では，全体の見学者は大きく減少しているなか，語り部への参加 人数は逆に増加しており, 震災遺構保存等のハードだけではなく ソフトの展開の重要性を感じているようである。

(3)では，震災遺構保存だけではなく，一般広場を活用した各種 ソフト展開で震災の記憶を伝えようとする活動を展開しようとし ているところであり(みなとのもり公園自体の開園は2010年と比 較的新しい)，これからもその内容推移の調查が必要である。

(4)について，まさしく施設の経営であり，時間の経過ととも に来場者が減少していくなかで苦労しているようすが伺えた。し かも，そのような中での指定管理者制度の導入も，現場の経営を 圧迫しており，長期的視点にたっての経営計画，震災関連施設の みへの来場者に頼らない，その施設独自での誘客促進の考え方が 重要であることなどが指摘された。

\section{（4）東北地方等へのアドバイス}

みなとのもり公園, 西宮震災記念碑公園, 北淡震災記念公園の 管理者からアドバイスを得た。各担当者から聞かれたこれからの 東北地方での震災記念公園等の整備に対するアドバイスは以下の ようなものであった。

- みなとのもり公園, 西宮震災記念碑公園, 北淡震災記念公園 : 人々の記憶は年とともに急速に薄れていくので、当初は遺族の反 対意見はあっても、できるだけ震災の経験と教訓について後世ま で伝える施設等を残していってほしい。

・西宮震災記念碑公園のヒアリングから : 被災者遺族の心情も変 化していくことを前提に，当初のデザインを固定的に考えるので はなく, その変化に柔軟に対応できるようなにしておくことが重 要である。
・北淡震災記念公園 : 維持管理については, 当初の来園者数が年 とともに減少する (1998 年度 282 万人 $\rightarrow 2011$ 年度 21 万人（表 -2）こと，それに伴い収入減少も避けられないなか，逆に施設 が順次供用開始されていき, 管理費や修綪費も増加していくので, 長期的に必要な経費をきちんと見積もり，それに対応した維持管 理計画が重要である。特に，レストラン等の関連施設は，震災の 記憶を伝える施設が仮になくても単独で成り立っていくことを目 指して計画を行うくらいの方針をもつことが重要である。

・北淡震災記念公園 : ハードによるものだけではなく, 語り部の 育成等ソフトによる対応が重要であり，そのような人材育成にも 取り組んでもらいたい。

•みなとのもり公園:地元とのつながりを常に意識しておくこと， 公園部局だけではなく他部局とも連携した市民力支援の仕組みづ くりを行うことが重要である。

\section{4. まとめ}

阪神大震災後の震災記念公園等の現状と課題についてヒアリン グを行い、その結果を分析することにより以下のことがわかった。 また，これらは今後の東北地方等における震災記念公園等の計画 づくりに対する示唆となるものであると考えられる。

(1)施設の類型化 : 震災の記憶を伝えようとする公園等に設けられ ている施設は、震災の記憶を伝えるための 4 つの類型の施設とそ れらの施設の利用者のための便益施設、合わせて 5 種類に類型化 できる。

(2)施設の評価 : 震災の記憶を伝えるための施設に対する現場の担 当者の評価は高い。今後の震災記念公園の整備計画を検討するに あたっては、これらの類型を参考とした施設を設置することが効 果的であると思われる。

(3)震災遺構保存の重要性 : 震災遺構保存施設は、公園の計画当初 は反対意見があっても、その後遺族を含めた市民の意識は変化し、 保存施設への評価は高くなるため、積極的に保存寸るべきである。 (4)柔軟性のある震災遺構保存施設等設計の必要性 : 震災遺構保存 や犠牲者を追悼する碑等を整備するにあたつては、遺族等市民の 考え方が時間の経過とともに変化しても対応できるように、柔軟 性のある施設設計(例えば刻銘の予備スペースを取っておくこと) が必要である。

(5)施設が有効に活用されるための方策の重要性 : 施設だけに頼ら ず、地元の人々が中心となったイベントの開催や語り部の導入な ど、各種の方策を展開することが重要である。

(6)有料制の施設を整備し管理運営する場合の留意点: 有料制の施 設を整備し管理運営を行う場合、震災の記憶が薄れるにつれて利 用者数は減少するので、それを見込んで施設の整備計画、管理運 営計画を考えることが重要である。

\section{引用文献}

1）国土交通省都市局公園緑地・景観課（2012）：東日本大震災復興祈念公 園検討会議説明資料,〈http://www.mlit.go.jp/common/000204826.pdf〉, 2012.9.15.参照

2) 橘俊光ほか (2005) : 阪神・淡路大震災の復旧, 復興における兵庫県の 公園緑地における取り組みの成果と課題 : ランドスケープ研究 68 (3), 207-211

3）田中充 (2005) : 震災から 10 年・神戸市の公園緑地に関わる市民の参 画と協㗢 : ランドスケープ研究 68 (3), 212-215 